\title{
The relationship between the degree of maternal iron deficiency anemia and fetal neonatal hypoxemia: A cross-sectional study
}

\author{
Maternal demir eksikliği anemisinin derecesi ile fetal neonatal hipoksemi \\ arasındaki ilişki: Kesitsel bir çalışma
}

\author{
İnci Kahyaoğlu, Serkan Kahyaoğlu*, Leyla Mollamahmutoğlu, Nuri Danışman \\ Department of Obstetrics and Gynecology (İ. Kahyaoğlu, MD), Ufuk University School of \\ Medicine, TR-06520 Ankara, Clinic of High Risk Pregnancy (S. Kahyaoğlu, MD, L, \\ Mollamahmutoğlu, MD, Assoc. Prof. N. Danışman, MD), Zekai Tahir Burak Women's Health \\ Teaching and Research Hospital, TR-06230 Ankara
}

\begin{abstract}
Aim. Chronic maternal iron deficiency anemia has been found to be related with preterm delivery, low birth weight and intrauterine growth retardation. The potential detrimental effects of maternal anemia on the transplacental fetal oxygen extraction during labor have not been investigated yet. Method. Upon the spontaneous initiation of delivery among 32 term pregnant women, half of them with hemoglobin values lower than $9.5 \mathrm{gr} / \mathrm{dL}$ as anemic group, have been included to the study. Arterial cord blood samples have been collected immediately after delivery. Neonatal Apgar scores, birth weight and cord blood analysis of $\mathrm{pH}, \mathrm{PaO}_{2}, \mathrm{PaCO}_{2}, \mathrm{O}_{2}$ saturation and $\mathrm{HCO}_{3}$ have been recorded. Results. The mean hemoglobin levels of the anemic and non-anemic patients were $7.69 \pm 1.14 \mathrm{gr} / \mathrm{dL}$ and $10.5 \pm 0.67 \mathrm{gr} / \mathrm{dL}$ respectively. Neonatal cord blood $\mathrm{PaO}_{2}$ and $\mathrm{O}_{2}$ saturation of the non-anemic patients were significantly higher than anemic patients ( $84.3 \mathrm{vs} .41 .3 \mathrm{mmHg}$ for $\mathrm{PaO}_{2}$ and $69.5 \%$ vs. $42.6 \%$ for $\mathrm{O}_{2}$ saturation respectively). No significant difference in cord blood $\mathrm{PaCO}_{2}, \mathrm{pH}$ and $\mathrm{HCO}_{3}$ levels were found between anemic and non anemic ones. Conclusion. Although third trimester maternal iron deficiency anemia decreases neonatal cord blood $\mathrm{PaO}_{2}$ and $\mathrm{O}_{2}$ saturation levels; apart from severe ones, it does not result in neonatal hypoxemia generally. The possible effects of maternal iron deficiency anemia that can deteriorate transplacental oxygen transport to the fetus and neonatal acid-base status of the newborn should be clarified by further studies based on the short and long term clinical results of neonatal hypoxemia in the newborn's physiological state.
\end{abstract}

Keywords: Maternal anemia, neonatal hypoxemia, cord blood

\section{Özet}

Amaç. Maternal kronik demir eksikliği anemisinin preterm eylem, düşük doğum ağırlıği ve intrauterin gelişme geriliği ile ilişkili olduğu bulunmuştur. Maternal aneminin doğum sırasında transplasental fetal oksijenizasyonu üzerine olumsuz etkileri henüz çalışılmış değildir. Yöntem. Spontan doğum eylemi başlayan, hemoglobin değeri 9,5gr/dL altında olan 16's1 anemik toplam 32 term gebe çalışmaya dahil edilmiştir. Doğumdan hemen sonra arteriyel kord kanı örnekleri toplanmıştır. Neonatal Apgar skorları, doğum ağırlıkları ve umbilikal kord pH, $\mathrm{PaO}_{2}, \mathrm{PaCO}_{2}, \mathrm{O}_{2}$ saturasyonu ve $\mathrm{HCO}_{3}$ değerleri kaydedilmiştir. Bulgular. Anemik ve anemik olmayan hastaların ortalama hemoglobin değerleri sirasıyla 7,69 $\pm 1,14 \mathrm{gr} / \mathrm{dL}$ ve $10,5 \pm 0,67 \mathrm{gr} / \mathrm{dL}$ 'dir. Anemik olmayan hastaların neonatal kord kanı $\mathrm{PaO}_{2}$ ve $\mathrm{O}_{2}$ satürasyonu değerleri anemik hastalardan anlamlı derecede daha yüksek bulunmuştur $\left(\mathrm{PaO}_{2}\right.$ için 84,3 vs. 41,3mmHg ve $\mathrm{O}_{2}$ satürasyonu için \%69,5 vs. $\% 42,6$, sirasıyla). Anemik ve anemik olmayan hastaların kord kanı $\mathrm{PaCO}_{2}, \mathrm{pH}$ ve $\mathrm{HCO}_{3}$ değerleri arasında fark bulunamamıştır. Sonuç. Her ne kadar, 9,5gr/dL'nin altındaki üçüncü trimester maternal hemoglobin seviyesi neonatal kord kan1 $\mathrm{PaO}_{2}$ ve $\mathrm{O}_{2}$ satürasyonunda azalmaya sebep olsa da, ciddi anemi dışında genel olarak neonatal hipoksemiye yol açmaz. Maternal demir eksikliği anemisinin fetüsün transplasental oksijen transportu ve neonatal asit-baz dengesi üzerine muhtemel etkileri, neonatal hipokseminin yenidoğanın fizyolojik durumuna uzun ve kısa dönemli klinik etkilerinin araştırıldığı çalışmalarla açıklığa kavuşturulmalıdır.

Anahtar sözcükler: Gebelik anemisi, yenidoğan hipoksemisi, kordon kanı 
Geliş tarihi/Received: August 07, 2012; Kabul tarihi/Accepted: October 15, 2012

\section{*Corresponding author:}

Dr. Serkan Kahyaoğlu, Yüksek Riskli Gebelik Kliniği, Zekai Tahir Burak Kadın Sağlığı Eğitim ve Araştırma Hastanesi, TR-06230 Ankara. E-mail: mdserkankahyaoglu@gmail.com

\section{Introduction}

An association between severe maternal anemia and adverse pregnancy outcome has been previously described by several studies $[1,2]$. Low birth weight, preterm labor, low Apgar scores and perinatal death are possible perinatal complications of maternal anemia [3-8]. Maternal third trimester anemia has not been thought to be in association with adverse perinatal outcome [5]. It is already a question whether moderate anemia affects the pregnancy outcome negatively. Both low and high hemoglobin $(\mathrm{Hb})$ status have been found important factors affecting perinatal outcome via diminished oxygen supply by low erythrocyte count and low uterine perfusion respectively [7]. However the Hb levels below $11 \mathrm{gr} / \mathrm{dL}$ is assumed as anemia during pregnancy that includes the plasma volume expansion exceeding erythrocyte expansion resultant with a physiological anemia in a normal pregnancy, the mean corpuscular volume (MCV) of the erythrocytes does not change substantially during pregnancy and a $\mathrm{Hb}$ concentration $<9.5 \mathrm{gr} / \mathrm{dL}$ concomitant with a MCV of <84fL indicates iron deficiency anemia. Hb concentrations of 9.5$11.5 \mathrm{gr} / \mathrm{dL}$ with a normal range MCV value (84-99fL) is accepted as optimal $\mathrm{Hb}$ values for fetal growth and well-being [4]. A significant fall in birthweight due to increase in prematurity rate and intrauterine growth retardation are potential consequences of maternal $\mathrm{Hb}$ levels below 8gr/dL during pregnancy [9].

During the pregnancy course of a woman, an average $\mathrm{Hb}$ value of $13.3 \mathrm{gr} / \mathrm{dL}$ falls to an average of $11 \mathrm{gr} / \mathrm{dL}$ at 36 weeks of gestation. The lowest $\mathrm{Hb}$ value is detected at second trimester around 20 weeks of gestation. Hb value is almost always constant up to 30 weeks of gestation and rises slightly thereafter in the third trimester. A physiological anemia with a $\mathrm{Hb}$ value not lower than $9.5 \mathrm{gr} / \mathrm{dL}$ occurs during pregnancy but mean corpusculary volume (MCV) of erytrocytes does not change. A MCV value of $<84 \mathrm{fL}$ with low $\mathrm{Hb}$ values indicate iron deficiency anemia leading to low oxygen supply to the fetus that increases the intrauterine growth restriction risk unlike physiological anemia of pregnancy [4]. Normal fetuses can tolerate maternal anemia without perinatal complications unless it reaches very low $\mathrm{Hb}$ values of $<8 \mathrm{gr} / \mathrm{dL}$ reflecting severe anemia. Maternal cardiac decompensation usually occurs when Hb levels fall below 5gr/dL [9].

However, routine supplementation with iron or folic acid has not resulted with a significant effect on perinatal outcome. The recently published randomised controlled trials have not revealed a precise relationship between maternal anemia and adverse perinatal outcome $[10,11]$. Intrapartum consequences of maternal third trimester anemia based on neonatal cord blood acid-base status analysis have not been exclusively evaluated with previous studies. We investigated whether maternal third trimester anemia detected with serum $\mathrm{Hb}$ levels of $<9.5 \mathrm{gr} / \mathrm{dL}$ as a cut-off level for iron deficiency anemia in pregnancy results in diminished oxygen supply to fetus and also whether this fetus can be exposed to low birth weight, growth restriction or intrapartum hypoxic complications during active labor because of chronic fetal antepartum hypoxia or not [4].

\section{Materials and methods}

This prospective study was conducted on 16 anemic $(\mathrm{Hb} \leq 9.5 \mathrm{gr} / \mathrm{dL})$ and 16 non-anemic healthy pregnant women $(\mathrm{Hb}>9.5 \mathrm{gr} / \mathrm{dL})$ delivering term singleton livebirths at term gestation (37-41 weeks) in an educational hospital. The study was approved by Ethics Committee of the hospital and written informed consents were obtained from all participants. Exclusion criteria were prolonged rupture of membranes ( $>24$ hours), fever, 
foul-smelling liquor, antepartum hemorrhage, pregnancy-induced hypertension, gestational diabetes mellitus, liver or kidney disorders, cigarette smoking and any other systemic illness. Gestational age was calculated either from the first day of the last menstrual period or from the first trimester ultrasonography examination for patients with unknown last menstrual date. Apart from the non-anemic ones, patients with iron deficiency anemia have not received regular iron supplementation during their current pregnancy. Maternal blood samples were obtained by iron-free polyethylene tubes from the mother's antecubital vein during the first stage of labor when the patient was admitted for labour. Neonatal cord blood samples were obtained immediately after the baby was born and once a 10-20 cm segment of the cord was doubly clamped. Cord blood sample was drawn into a $2 \mathrm{~mL}$ syringe which is flushed with heparin. Fetal or newborn acidemia has been defined as an umbilical artery blood $\mathrm{pH}$ of less than 7.2 [12]. All blood samples were immediately transported to the laboratory after they were collected for the measurement of maternal $\mathrm{Hb}$, hematocrit, ferritin, $\mathrm{MCV}$ and neonatal cord blood $\mathrm{pH}$, $\mathrm{pO}_{2}, \mathrm{pCO}_{2}, \mathrm{O}_{2}$ saturation. Among patients with and without iron deficiency anemia; we compared maternal age (years), gestational age at delivery (weeks), birthweight (grams), $\mathrm{Hb}$ level $(\mathrm{gr} / \mathrm{dL}), \mathrm{MCV}(\mathrm{fL})$, ferritin $(\mu \mathrm{g} / \mathrm{L})$ and neonatal cord blood $\mathrm{PaO}_{2}(\mathrm{mmHg})$, $\mathrm{PaCO}_{2}(\mathrm{mmHg}), \mathrm{O}_{2}$ saturation (\%), $\mathrm{HCO}_{3}, \mathrm{pH}$ levels and 5. minute Apgar scores of the neonates. Patients' previous $\mathrm{Hb}$ levels have also been reviewed from the hospital records and patients with second trimester anemia have been excluded from the study. Statistical power analysis of the study was made based on the previous study performed by Stefanović et al. [13] on 2005 that was conducted among 32 patients with an $\alpha: 0.05$ error margin and minimum $80 \%$ power for statistical significance. Simple randomization technique was used by including one of each two eligible patients who were accepted to the delivery ward.

\section{Statistical analysis}

Collected data were analysed by means of the IBM SPSS Statistics Software (19.0, SPSS Inc., Chicago, IL, USA). Whether the distributions of continous variables were normal or not, was determined by the Shapiro Wilk test. Descriptive statistics for continous variables were shown as mean \pm standart deviation or median (minimum-maximum). The mean differences between groups were compared by Independent Samples $\mathrm{T}$ test. Otherwise, Mann-Whitney U test was applied for the comparisons of the median values. Nominal data were analyzed by Pearson's Chi-square where appropriate. A p value less than 0.05 was consideredas statistically significant.

\section{Results}

The majority of the participants were multipar (56.3\%) and majority of the patients had low socioeconomic status (65.6\%). Twenty two (68.8\%) pregnant women had body mass index (BMI) values between 19-26 while only 2 (6.3\%) had BMI values below 19 and 8 had above 26. Only 3 out of 32 had delivered by cesarean section while the remaining had delivered vaginally. When the cases were categorized according to presence or absence of anemia, no significant difference was found between the anemic and non-anemic patients regarding the age, gestational age at delivery and the birth weight of the babies ( $p>0.05)$ (Table 1). The mean $\mathrm{Hb}$ levels of the anemic and non-anemic patients were $7.69 \pm 1.14 \mathrm{gr} / \mathrm{dL}$ and $10.5 \pm 0.67$ respectively $(\mathrm{p}<0.05)$. The MCV and ferritin levels of the anemic group were significantly lower when compared to non-anemic group (Table 1). In addition, neonatal cord blood $\mathrm{PaO}_{2}$ and $\mathrm{O}_{2}$ saturation of the non-anemic patients were significantly higher than anemic patients $\left(84.3\right.$ vs. $41.3 \mathrm{mmHg}$ for $\mathrm{PaO}_{2}$ and $69.5 \%$ vs $42.6 \%$ for $\mathrm{O}_{2}$ saturation respectively). No significant difference in cord blood $\mathrm{PaCO}_{2}, \mathrm{pH}$ and $\mathrm{HCO}_{3}$ levels were found between anemic and non anemic ones ( $\left.>0.05\right)$. ROC curve analysis revealed that the $\mathrm{Hb}$ cut off value that predicts neonatal cord blood low $\mathrm{pH}$ with $67 \%$ sensitivity and $78 \%$ specificity is $10.5 \mathrm{gr} / \mathrm{dL}$ ( $\mathrm{AUC}=0.66 ; \mathrm{p}=0.16,95 \% \mathrm{CI}=0.36$ 0.95) (Figure 1). The sensitivity for detection of low neonatal cord blood $\mathrm{pH}$ substantially increased to $67 \%$ at maternal $\mathrm{Hb}$ level of $8 \mathrm{gr} / \mathrm{dL}$ with low specificity levels. 
When the newborns were categorized according to birthweight at gestational age at birth, 3 out of 16 in anemic and 4 out of 16 in nonanemic group were found to be small for gestational age, while the remaining in both groups were appropriate for the gestational age $(p>0,05)$. Two newborns in the study group whose mothers had severe anemia $(6$ $\mathrm{gr} / \mathrm{dL}$ and $5.4 \mathrm{gr} / \mathrm{dL}$ respectively) were found to have low neonatal cord blood $\mathrm{pH}$ levels $(<7.10)$ reflecting their hypoxemic state. Both of these two newborns had 1st minute Apgar scores of 3rd and 5th minute Apgar scores of 7 following a short period of $\mathrm{O}_{2}$ therapy with oxygen mask utilization. In this study, none of the newborns were sent to the neonatal intensive care unit.

Table 1. The characteristics and the laboratory values of anemic and non-anemic groups.

\begin{tabular}{|c|c|c|c|}
\hline & $\begin{array}{l}\text { Anemic } \\
(\mathrm{Hb} \leq 9.5 \mathrm{gr} / \mathrm{dL})\end{array}$ & $\begin{array}{l}\text { Non-anemic } \\
(\mathrm{Hb}>9.5 \mathrm{gr} / \mathrm{dL})\end{array}$ & $\begin{array}{l}P \\
\text { values } 9\end{array}$ \\
\hline Maternal age (years) & $25.1 \pm 4.4$ & $26.0 \pm 4.7$ & $0.594 *$ \\
\hline Gestational age at delivery (weeks) & $39.0 \pm 1.2$ & $38.9 \pm 1.4$ & $0.893 *$ \\
\hline Birth weight (gram) & $3093 \pm 335$ & $3135 \pm 429$ & $0.757 *$ \\
\hline Maternal hemoglobin $(\mathrm{gr} / \mathrm{dL})$ & $7.6 \pm 1.1$ & $10.5 \pm 0.6$ & $0.001 * *$ \\
\hline Maternal hematocrit (\%) & $22.4 \pm 2.6$ & $32.6 \pm 1.3$ & $0.001 * *$ \\
\hline Maternal MCV (fL) & $67.8 \pm 4.6$ & $84.2 \pm 2.7$ & $0.001 * *$ \\
\hline Maternal Ferritin $(\mu \mathrm{g} / \mathrm{L})$ & $5.3 \pm 1.9$ & $12.2 \pm 6.1$ & $0.001 * *$ \\
\hline Neonatal cord blood $\mathrm{PaO}_{2}(\mathrm{mmHg})$ & $41.3 \pm 40.4$ & $84.3 \pm 54.6$ & $0.017 * *$ \\
\hline Neonatal cord blood $\mathrm{PaCO}_{2}(\mathrm{mmHg})$ & $47.6 \pm 14.8$ & $43.7 \pm 12.7$ & $0.434 *$ \\
\hline Neonatal cord blood $\mathrm{O}_{2}$ saturation $(\%)$ & $42.6 \pm 28.9$ & $69.6 \pm 32.7$ & $0.019 *$ \\
\hline Neonatal cord blood $\mathrm{HCO}_{3}(\mathrm{meq} / \mathrm{L})$ & $20.0 \pm 4.4$ & $20.0 \pm 2.7$ & $0.999 * *$ \\
\hline Neonatal cord blood $\mathrm{pH}$ & $7.27 \pm 0.11$ & $7.29 \pm 0.08$ & $0.672 * *$ \\
\hline 5th minute Apgar score & $7.40 \pm 2.20$ & $7.60 \pm 2.20$ & $0.564 * *$ \\
\hline
\end{tabular}

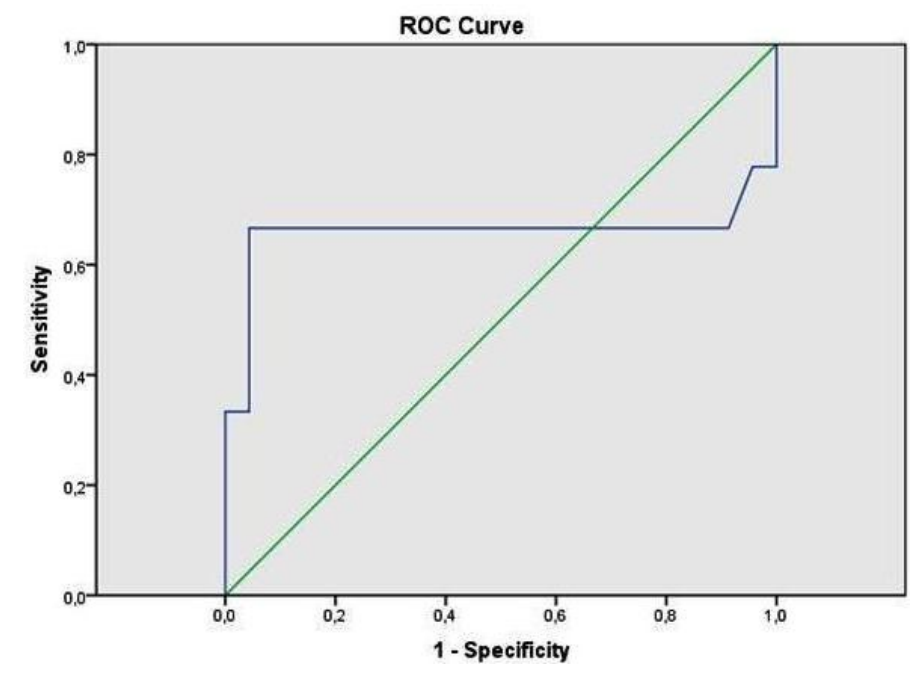

Figure 1. The ROC curve for demonstrating the direct proportional relationship between maternal anemia and neonatal cord blood $\mathrm{pH}$ level $(\mathrm{AUC}=\mathbf{0 . 6 6} ; \mathrm{p}=\mathbf{0 . 1 6}, 95 \% \mathrm{CI}=\mathbf{0 . 3 6}-\mathbf{0 . 9 5})$.

\section{Discussion}

The result of this study demonstrated that maternal $\mathrm{Hb}$ concentration affects the umbilical cord $\mathrm{PaO}_{2}$ and $\mathrm{O}_{2}$ saturation but not the $\mathrm{pH}$. Although the relationship between maternal anemia before second trimester pregnancy and adverse perinatal outcomes was more clear, the possible deleterious effect of third trimester iron deficiency anemia on fetal oxygenation during labour has not been studied well before. Umbilical cord blood $\mathrm{pH}$ and 
acid- base analysis is especially useful for evaluation of the delivery of an infant with a low Apgar score as well as for pregnancies complicated by meconium staining of the amniotic fluid. During pregnancy due to the expansion of the maternal plasma volume, a physiological anemia occurs which can cause a decrease of $\mathrm{Hb}$ from 13.3gr/dL to an average of $11 \mathrm{gr} / \mathrm{dL}$ at $36 \mathrm{th}$ weeks of gestation. While $\mathrm{Hb}$ concentration decreases, MCV does not change. A MCV value of $<84 \mathrm{fL}$ with a $\mathrm{Hb}$ concentration $<9.5 \mathrm{gr} / \mathrm{dL}$ indicates iron deficiency anemia [4]. Most of the studies suggest that a fall in maternal $\mathrm{Hb}$ below $11.0 \mathrm{~g} / \mathrm{dL}$ is associated with a significant rise in perinatal mortality rate. When the maternal $\mathrm{Hb}$ levels fall below $8.0 \mathrm{~g} / \mathrm{dL}$, there is usually a 2 to 3 -fold increase in perinatal mortality rate. This rate increases to 8-10 fold when the $\mathrm{Hb}$ levels fall below 5.0g/dL [9]. An association between severe maternal anemia before midpregnancy and adverse pregnancy outcome has been previously described by several other studies [1,2]. Duthie et al. [14] found a significantly lower mean birthweight in infants delivered by severely anemic mothers, while Klebanoff et al. [15] and Lieberman et al. [16] observed a significant association between anemia and preterm delivery. Anemia and iron deficiency by causing causing hypoxia and increased norepinephrine concentrations can induce maternal and fetal stress which stimulate the synthesis of corticotrophin releasing hormone $(\mathrm{CRH})$ from fetal hypophysis gland leading to increased fetal adrenal gland secretion of cortisol. Elevated fetal CRH is a major risk factor for preterm labor. In adrenelectomised pregnant sheep fetuses the pregnancies have been prolonged and the initiation of labor have been inhibited [17]. A significant fall in birth weight due to increase in prematurity rate and intrauterine growth retardation has been reported by other authors when maternal $\mathrm{Hb}$ levels were below $8.0 \mathrm{~g} / \mathrm{dL}$ [12]. We could not demonstrate any significant difference in birthweight of newborns between anemic and non-anemic groups. As the previous $\mathrm{Hb}$ values were not included in the study, we could not detect how long the patients were anemic. Low Hb concentrations can cause a state of chronic hypoxia. During the acute phase of reductions in fetal oxygen delivery, increase in oxygen extraction could maintainan fetal oxygen consumption. With sustained hypoxia over several days, the ovine fetuses responds to long term reductions in oxygenation with the decrease of oxygen consuming processes like growth restriction or diminished fetal activity [17]. Also recent studies with prolonged but gradual decreases of oxygen delivery over the last 3 to 4 weeks of gestation induced by maternal anemia or restricting uterine blood flow have resulted in growth restricted fetuses but without hypoxemia [18] Karaşahin et al. [10] and Sekhavat et al. [11] found that preterm birth, preeclampsia, intrauterine growth restriction rates and neonatal low birthweight rates were higher in severely anemic pregnant patients than non-anemic ones. Stefanović et al. [13] suggested that $\mathrm{Hb}$ content of $<6 \mathrm{gr} / \mathrm{dL}$ is strongly associated with marked fetal hemodynamic adaptation and must be treated with acute red cell transfusion whilst moderate anemia (maternal $\mathrm{Hb}>6 \mathrm{gr} / \mathrm{dL}$ ) is not sufficient to trigger fetal blood flow redistribution and can be treated with oral iron intake. Also in another study on pregnant ewes showed that uterine blood flow failed to increase in anemic ewes, while steadily increasing in controls. Arterial $\mathrm{PO}_{2}$ and oxygen content in the fetuses of anemic ewes fell transiently below controls but did not persist [19]. As far as we know this study was the first in the literature that intends to evaluate maternal third trimester anemia on fetal neonatal oxygenation. In our study, as most of the newborns of the anemic mothers are appropriate for the gestational age, it can be hypothesized that the oxygen demand of the fetus is balanced by increasing oxygen extraction and their growth is not restricted yet. But the decrease in $\mathrm{PaO}_{2}$ and $\mathrm{O}_{2}$ saturation of the cord blood as the $\mathrm{Hb}$ level of the anemic women fall, could be explained by the acute fetal stress and acute increase in oxygen demand due to labour. As the contractions increase and labour progress, fetus demands more oxygen than the erythrocytes could carry, so the $\mathrm{PaO}_{2}$ decreases. This increased demand can easily be balanced in non- anemic counterparts as it was demonstrated in our study. The longterm clinical significance of low neonatal $\mathrm{pH}, \mathrm{PaO}_{2}$ and $\mathrm{O}_{2}$ saturation levels for the vigorous newborn has not been studied before. 
In conclusion, anemia is a preventable cause of many adverse pregnancy outcomes. Detection and treatment of iron deficiency anemia could reduce the risks for both the mother and the fetus when detected early in pregnancy. However, we could not detect an increased neonatal hypoxemia risk for iron deficiency anemia patients with a third trimester $\mathrm{Hb}$ levels $<9.5 \mathrm{gr} / \mathrm{dL}$, based on the previous studies severe chronic maternal anemia reflected as $\mathrm{Hb}$ levels $<8 \mathrm{gr} / \mathrm{dL}$ can impede transplacental oxygen transport to the fetus as maternal and fetal oxygen demands substantially increase especially during active labor [9]. Whether the third trimester chronic anemia correction by blood products transfusion before and/ or during active labor facilitates the newborn's acid- base status or not remains to be proven. Besides, the possible effects of third trimester chronic maternal anemia on neonatal acid-base status of the newborn according to the degree of maternal anemia should be clarified by further studies based on the short and long term clinical significance of neonatal hypoxemia on the newborn's physiological state.

\section{References}

1. Allen LH. Biological mechanisms that might underlie iron's effects on fetal growth and preterm birth. J Nutr 2001; 131: 581S-589S.

2. Goel A, Jain V, Gupta I, Varma N. Serial serum ferritin estimation in pregnant women at risk of preterm labor. Acta Obstet Gynecol Scand 2003; 82: 129-32.

3. Carles G, Tobal N, Raynal P, Herault S, Beucher G, Marret H, Arbeille P. Doppler assessment of the fetal cerebral hemodynamic response to moderate or severe maternal anemia. Am J Obstet Gynecol 2003; 188: 794-9.

4. Steer PJ. Maternal hemoglobin concentration and birth weight. Am J Clin Nutr 2000; 71: 1285S-7S.

5. Scholl TO, Reilly T. Anemia, iron and pregnancy outcome. J Nutr 2000; 130(2S Suppl): 443S-447S.

6. Rasmussen K. Is There a Causal Relationship between Iron Deficiency or IronDeficiency Anemia and Weight at Birth, Length of Gestation and Perinatal Mortality? J Nutr 2001; 131: 590S-601S.

7. Bondevik GT, Lie RT, Ulstein M, Kvale G.Maternal hematological status and risk of low birth weight and preterm delivery in Nepal. Acta Obstet Gynecol Scand 2001; 80: 402-8.

8. Chang SC, O'Brien KO, Nathanson MS, Mancini J, Witter FR. Hemoglobin concentrations influence birth outcomes in pregnant African-American adolescents. J Nutr 2003; 133: 2348-55.

9. Kalaivani K. Prevalence \& consequences of anaemia in pregnancy. Indian J Med Res 2009; 130: 627-33.

10. Karaşahin E, Ceyhan ST, Göktolga U, Keskin U, Başer İ. Maternal Anemi ve Perinatal Sonuçlar. Perinatoloji Dergisi 2007; 15: 127-30.

11. Sekhavat L, Davar R, Hosseinidezoki S. Relationship between maternal hemoglobin concentration and neonatal birth weight. Hematology 2011; 16: 3736.

12. ACOG technical bulletin. Umbilical artery blood acid-base analysis. Number 216--November 1995. (Replaces No. 127, April 1989). Int J Gynaecol Obstet 1996; 52: 305-10.

13. Stefanović M, Milosavljević M, Radović-Janošević D, Kutlešić R, Vukomanović P. Maternal anemia and fetal cerebral hemodynamic response-doppler assessment. Medicine and Biology 2005; pp: 93-6.

14. Duthie SJ, King PA, To WK, Lopes A, Ma HK. A case controlled study of pregnancy complicated by severe maternal anaemia. Aust N Z J Obstet Gynaecol 1991; 31: 125-7.

15. Klebanoff MA, Shiono PH, Selby JV, Trachtenberg AI, Graubard BI. Anemia and spontaneous preterm birth. Am J Obstet Gynecol 1991; 164: 59-63.

16. Lieberman E, Ryan KJ, Monson RR, Schoenbaum SC. Association of maternal hematocrit with premature labor. Am J Obstet Gynecol 1988; 159: 107-14. 
17. Hooper SB, Coulter CL, Deayton JM, Harding R, Thorburn GD. Fetal endocrine responses to prolonged hypoxemia in sheep. Am J Physiol 1990; 259: R703-8.

18. Richardson BS, Bocking AD. Metabolic and circulatory adaptations to chronic hypoxia in the fetus. Comp Biochem Physiol A Mol Integr Physiol 1998; 119: 717-23.

19. Mostello D, Chalk C, Khoury J, Mack CE, Siddiqi TA, Clark KE. Chronic anemia in pregnant ewes: maternal and fetal effects. Am J Physiol 1991; 261 (5 Pt 2): R1075-83. 